\title{
Risk factors for acquisition of endemic blastomycosis
}

\author{
Maxym Choptiany LLB ${ }^{1}$, Lyle Wiebe CRSP CPHI ${ }^{2}$, Bill Limerick CPHI ${ }^{2}$, Pete Sarsfield MD², Mary Cheang MMath ${ }^{3}$, \\ Bruce Light $\mathrm{MD}^{4}$, Greg Hammond $\mathrm{MD}^{4}$, Kerry MacDonald $\mathrm{MD}^{5}$, Elly Trepman $M D^{6,7}$, Peter Pappas $\mathrm{MD}^{8}$, \\ John M Embil MD ${ }^{4,7}$
}

M Choptiany, L Wiebe, B Limerick, et al. Risk factors for acquisition of endemic blastomycosis. Can J Infect Dis Med Microbiol 2009;20(4):117-121.

BACKGROUND: Blastomycosis is potentially fatal, but environmental risk factors for acquiring blastomycosis are not well established. METHOD: Matched cross-sectional questionnaire of 112 patients with history of blastomycosis and 118 control subjects in Manitoba and northwestern Ontario.

RESULTS: The most common tissues involved with blastomycosis were pulmonary, skin and soft tissues, and bone. A significantly greater proportion of patients with blastomycosis than control subjects were involved in outdoor occupations. A significantly greater percentage of patients with blastomycosis were immunosuppressed either from collagen vascular disease or immunosuppressive therapy, or had hypothyroidism. A significant association between canine and human blastomycosis was not observed.

CONCLUSIONS: Independent risk factors for development of blastomycosis included immunosuppression for any reason (including drugs or disease), collagen vascular disease, being an outdoor worker, and having a coworker with blastomycosis. Canine blastomycosis was not a risk factor for human disease in dog owners.

Key Words: Blastomyces dermatitidis; Fungus; Infection; Pulmonary

\section{Les facteurs de risques d'acquisition d'une blastomycose endémique}

HISTORIQUE : La blastomycose peut être fatale, mais les facteurs de risque environnementaux de son acquisition ne sont pas bien établis.

MÉTHODOLOGIE : Un questionnaire transverse apparié auprès de 112 patients ayant des antécédents de blastomycose et de 118 sujets témoins au Manitoba et au nord-ouest de l'Ontario.

RÉSULTATS : Les tissus pulmonaires, les tissus cutanés, les tissus mous et les os sont les plus touchés par la blastomycose. Une proportion considérablement plus élevée de patients ayant une blastomycose que de sujets témoins avaient un travail extérieur. Un pourcentage beaucoup plus élevé de patients atteints de blastomycose étaient immunosupprimés à cause d'une collagénose avec manifestation vasculaire, d'une thérapie immunosuppressive ou d'une hypothyroïdie. On n'a pas observé d'association significative entre les formes canine et humaine de la blastomycose.

CONCLUSIONS : Les facteurs de risque indépendants d'acquisition de la blastomycose incluaient une immunosuppression pour quelque raison que ce soit (y compris des médicaments ou des maladies), une collagénose avec manifestation vasculaire, un travail en plein air et le fait d'avoir un collègue de travail atteint de blastomycose. La blastomycose canine n'était pas un facteur de risque de maladie humaine chez les propriétaires de chiens.
B lastomycosis is a potentially fatal systemic and cutaneous B fungal infection of humans and animals caused by Blastomyces dermatitidis, a thermally dimorphic fungus that exists in mycelial form in the soil of warm, moist, wooded areas that are rich in organic debris (1-4). The clinical manifestations of blastomycosis are highly varied, ranging from acute to subclinical and chronic pulmonary infection and systemic pyogranulomatous disease. Initial infection occurs primarily through the lungs via inhalation of aerosolized conidia released by the fungus from disrupted soil (5). The conidia convert to thick-walled budding yeast in the lungs $(5,6)$. Hematogenous dissemination may occur, most commonly involving the skin, bones and genitourinary system $(7,8)$.

Blastomyces dermatitidis is endemic in the Canadian province of Manitoba ( 0.62 cases per 100,000 population), the Kenora region of the province of Ontario (7.11 cases per 100,000 population) $(7,9)$, and the southcentral and upper midwestern United States, including areas surrounding the
Great Lakes. B dermatitidis also is endemic in Wisconsin (1.3 cases per 100,000 population) and Mississippi (1.4 cases per 100,000 population), as well as parts of Missouri, Kentucky, Tennessee, Arkansas and Alabama (10-14). Epidemiological information has been derived primarily from investigations of outbreaks and small case series. Although a number of studies have been undertaken to define the incidence and prevalance of blastomycosis, determining these epidemiological parameters has been difficult because $B$ dermatitidis cannot be readily recovered from nature and there is no suitable, sensitive, and specific skin or serological test to confirm infection; therefore, cases may be undetected or underdiagnosed (6). Most epidemiological studies have depended on growth of $B$ dermatitidis in cultures of clinical specimens or direct histological visualization to establish the diagnosis $(6,12)$.

The environmental risk factors for acquiring blastomycosis have been evaluated during outbreaks but have not been conclusively established. These risk factors are presumed to include

${ }^{1}$ Faculty of Medicine, University of Manitoba, Winnipeg, Manitoba; ${ }^{2}$ Northwestern Health Unit, Kenora, Ontario; ${ }^{3}$ Department of Community Health Sciences, Statistical Consulting Unit; ${ }^{4}$ Department of Medicine, Section of Infectious Diseases, University of Manitoba, Winnipeg, Manitoba; ${ }^{5}$ Lake of the Woods District Hospital, Kenora, Ontario; ${ }^{6}$ Department of Orthopaedic Surgery, Grand Itasca Clinic $\mathcal{E}$ Hospital, Grand Rapids, Minnesota, USA; ${ }^{7}$ Department of Medical Microbiology, University of Manitoba, Winnipeg, Manitoba; ${ }^{8}$ Division of Infectious Diseases, University of Alabama at Birmingham, Birmingham, Alabama, USA

Correspondence: Dr John M Embil, Infection Prevention and Control Unit, Health Sciences Centre, MS673-820 Sherbrook Street, Winnipeg, Manitoba R3A 1R9. Telephone 204-787-4654, fax 204-787-2989, e-mail jembil@hsc.mb.ca 
exposure to endemic regions and exposure to soil or dust clouds resulting from disruption of soil; however, specific outdoor occupations or activities have not been confirmed $(1,11,14$ 17). To date, two case control studies have been undertaken to define the risk factors for acquisition of blastomycosis. In one case control study from Mississippi, the independent risk factors for development of blastomycosis were black race and prior history of pneumonia, but neither environmental nor socioeconomic risk factors were detected (13). This is in contrast to previously noted studies and reports that have indicated that race and gender do not appear to be specific risk factors for the acquisition of blastomycosis $(14,17,18)$. In the other case control study, a disproportionate number of human and canine cases were associated with exposure to waterways of a river (8). Immunosuppression also may be an important risk factor $(19,20)$, and blastomycosis has been reported during pregnancy, in diabetic patients, organ transplant recipients and individuals infected with the human immunodeficiency virus (HIV) (19-23).

The most frequently affected species by $B$ dermatitidis are dogs and humans. It has been speculated that dogs may serve as a sentinel marker for human disease, where dogs present with systemic infection before their owners, leading to early suspicion of human infection by astute veterinarians $(10,24-27)$. It has been speculated that disease is acquired simultaneously in dogs and their owners after exposure to the same source of the pathogen (27), but this remains to be confirmed.

We hypothesized that risk factors for the acquisition of blastomycosis may be further characterized from a review of a clinical series of patients with blastomycosis.

\section{METHODS}

\section{Subjects}

Patients with blastomycosis were defined as individuals who had a clinically compatible illness, such as subacute pneumonia or characteristic skin lesions, and from whom $B$ dermatitidis was isolated by culture or visualized as characteristic broad-based budding yeast in a clinical specimen (12). In northwestern Ontario, patients were sought by newspaper advertisements and correspondence to local physicians seeking patients who had a history of blastomycosis. In Manitoba, patients were sought by newspaper advertisements and through a confidential mail solicitation organized through Manitoba Health (the provincial health department). A form letter from the investigator requesting participation in the study was forwarded to individuals who had an International Classification of Disease (ninth revision) diagnosis code of 116.0 (28) for blastomycosis recorded in either hospital or medical claims from 1992 to 2002. To maintain patient confidentiality, the investigators were not aware of the identity or number of people to whom letters were sent. The individuals to whom the letters were sent were provided with a telephone number to contact the investigators to enroll voluntarily in the study. The study population of people with confirmed blastomycosis who responded to the advertisements or letters consisted of 112 patients.

Patients who agreed to participate in the study were asked to identify two neighbors who never had any clinical manifestations compatible with blastomycosis including a laboratoryconfirmed diagnosis of blastomycosis or clinical symptoms such as nonresolving skin lesions, chronic cough or chronic nonresolving pneumonia. A total of 230 subjects participated in the study: 112 patients with blastomycosis and 118 control subjects ( 28 patients had no control subject, 52 patients had one control subject, and 32 patients had two control subjects [some data were not available for two other control subjects]; these three groups of patients were similar, so the matching appeared valid for statistical analysis). Informed consent was obtained. The study was approved by the Research Ethics Board, Faculty of Medicine, University of Manitoba, Manitoba Health's Health Information Privacy Committee, and the ethics review boards of the specific facilities where patient records were reviewed.

\section{Definitions}

Indoor nonlabourers included nonlabour workers such as shop clerks, teachers, physicians, attorneys and accountants. Indoor labourers included mechanics and factory workers. Outdoor workers included policemen, fire fighters, ambulance attendants, foresters and heavy equipment operators.

\section{Questionnaire}

A standardized questionnaire designed for the study was provided to all subjects and returned to the investigators upon completion. Questions pertaining to blastomycosis treatment, hospitalization, clinical manifestations and investigations were included in the questionnaire for blastomycosis patients but omitted from the control questionnaire. Medical records were reviewed when available to confirm or add to information obtained from the questionnaire.

Information collected from the questionnaires and medical records included specific details about anatomical site of blastomycosis involvement, demographics, occupation, residence, travel, tobacco use, alcohol consumption, recreational drug use, and marital and offspring status. Activities and potential exposures were noted on the questionnaire, including farming, landscaping, using manure as fertilizer, and breeding animals; camping, hunting, hiking or caving (spelunking); excavating, demolition of buildings, living near a construction site, construction work and heavy equipment operation; lumber work or forestry, sawmill work, exposure to woodpiles, chopping wood, working underneath cottages, sheds or houses; exposure to septic beds, activities along waterways including fishing and swimming; and gathering of berries, mushrooms, wild rice and flowers.

Questions about pets included ownership or contact with pets, type of pets, and whether a pet dog was diagnosed with blastomycosis within 12 months before diagnosis. Pre-existing medical conditions and comorbidities listed on the questionnaire included cardiac, pulmonary, liver, kidney, collagen vascular, thyroid or blood disease; cancer, diabetes, organ transplantation, immunosuppression, use of corticosteroids or other immunosuppressive agents; and HIV infection.

\section{Data analysis}

Statistical analysis was performed using statistical software (SAS for Windows, Version 9.1, SAS Institute Inc, USA). Stratified Mantel-Haenszel $\chi^{2}$ tests were used to compare proportions of categorical variables between patients with blastomycosis and control subjects, and paired analysis of variance and Friedman's tests were used to compare means or medians of continuous variables. Odds ratios (ORs) and 95\% CIs were 
TABLE 1

Tissue from which Blastomyces dermatitidis was identified ( $n=112$ patients)

\begin{tabular}{|c|c|c|c|c|}
\hline \multicolumn{3}{|l|}{ Tissue } & \multicolumn{2}{|c|}{ Patients, n (\%)* } \\
\hline \multicolumn{3}{|c|}{ Pulmonary (lungs and/or pleura) } & \multicolumn{2}{|c|}{$104(93)$} \\
\hline \multicolumn{3}{|c|}{ Skin and soft tissue } & \multicolumn{2}{|c|}{$24(21)$} \\
\hline \multicolumn{3}{|l|}{ Bone } & \multicolumn{2}{|c|}{$11(10)$} \\
\hline \multicolumn{3}{|l|}{ Lymph nodes } & \multicolumn{2}{|c|}{$8(7)$} \\
\hline \multicolumn{3}{|l|}{ Joint } & \multicolumn{2}{|c|}{$5(4)$} \\
\hline \multicolumn{3}{|c|}{ Central nervous system (brain and/or spinal cord) } & \multicolumn{2}{|c|}{$3(3)$} \\
\hline \multicolumn{3}{|c|}{ Urinary system (bladder and/or kidney) } & \multicolumn{2}{|c|}{$2(2)$} \\
\hline \multicolumn{3}{|l|}{ Prostate } & \multicolumn{2}{|c|}{$2(2)$} \\
\hline \multicolumn{3}{|c|}{ Gynecological } & \multicolumn{2}{|c|}{$1(1)$} \\
\hline \multicolumn{3}{|l|}{ Liver } & \multicolumn{2}{|c|}{$1(1)$} \\
\hline \multicolumn{3}{|l|}{ Spleen } & \multicolumn{2}{|c|}{$1(1)$} \\
\hline \multicolumn{3}{|c|}{ Endocrine (pancreas) } & \multicolumn{2}{|c|}{$1(1)$} \\
\hline \multicolumn{5}{|c|}{$\begin{array}{l}\text { *Total percentage exceeds } 100 \% \text { because some subjects had multiple tissues } \\
\text { involved }\end{array}$} \\
\hline \multicolumn{5}{|c|}{$\begin{array}{l}\text { TABLE } 2 \\
\text { Risk factors for blastomycosis in } 112 \text { patients with } \\
\text { blastomycosis }\end{array}$} \\
\hline Risk factor & $\begin{array}{l}\text { Patients, } \\
\text { n (\%) }\end{array}$ & $\begin{array}{l}\text { Controls, } \\
\text { n (\%) }\end{array}$ & $\begin{array}{l}\text { Odds ratio } \\
(95 \% \mathrm{Cl})\end{array}$ & $\mathbf{P}$ \\
\hline \multicolumn{5}{|l|}{ Sex } \\
\hline Male & $63(56)$ & $48(41)$ & \multirow[t]{2}{*}{1.7 (1.0 to 2.8$)$} & $<0.05$ \\
\hline Female & $49(44)$ & $70(59)$ & & \\
\hline \multicolumn{5}{|c|}{ Occupation type* } \\
\hline Outdoor & $26(24)$ & $12(10)$ & \multirow[t]{2}{*}{2.5 (1.2 to 7.5$)$} & $<0.02$ \\
\hline Indoor & $84(76)$ & $107(91)$ & & \\
\hline
\end{tabular}

${ }^{*}$ Data not available in 2 of the 112 patients with blastomycosis

calculated. Adjusted ORs were estimated by matched conditional logistic regression modelling. Independent predictors were determined after excluding the nonsignificant predictors in a series of backward stepwise modeling. Level of statistical significance was defined by $\alpha=0.05$.

\section{RESULTS}

The time from diagnosis to date of completion of the study ranged from 1.3 to 251 months, with a median of 36 months and mean of 52 months. The most common tissues involved with blastomycosis lesions were the pulmonary system, skin and soft tissues, and bone (Table 1).

Risk factors significantly associated with blastomycosis included male sex and outdoor occupation (Table 2). A significantly greater percentage of patients with blastomycosis than control subjects were immunosuppressed either from collagen vascular disease or immunosuppressive therapy (Table 3). Hypothyroidism was significantly more frequent in patients with blastomycosis than control subjects (Table 3).

Patients with blastomycosis had a significantly greater frequency of drug abuse than control subjects (Table 4). There were no differences between patients with blastomycosis and control subjects in history of alcohol or family social history (Table 4).

Although patients with blastomycosis were more frequently involved in outdoor occupations than control subjects (Table 2), there was no increased risk of blastomycosis identified from specific activities, specific occupations, occupational factors
TABLE 3

Medical history in $\mathbf{1 1 2}$ patients with blastomycosis and 118 control subjects

\begin{tabular}{|c|c|c|c|c|}
\hline Medical condition & $\begin{array}{l}\text { Patients, } \\
\text { n (\%) }\end{array}$ & $\begin{array}{l}\text { Controls, } \\
\text { n (\%) }\end{array}$ & $\begin{array}{l}\text { Odds ratio } \\
(95 \% \mathrm{Cl})\end{array}$ & $\mathbf{P}$ \\
\hline Pulmonary disease* & $18(16)$ & $14(12)$ & 1.8 (0.8 to 4.2$)$ & NS \\
\hline Liver disease & $2(2)$ & $1(1)$ & $3.0(0.2$ to 37.7$)$ & NS \\
\hline Kidney disease & $1(1)$ & $0(0)$ & Not estimable & NS \\
\hline $\begin{array}{l}\text { Collagen vascular } \\
\text { disease }^{\dagger}\end{array}$ & $15(13)$ & $8(7)$ & 4.0 (1.3 to 12.1$)$ & $<0.004$ \\
\hline Cancer & $5(4)$ & $1(1)$ & 6.5 (0.7 to 61.1$)$ & NS \\
\hline Blood disorder & $1(1)$ & $1(1)$ & 1.0 (0.1 to 16.0$)$ & NS \\
\hline Heart disease & $6(5)$ & $4(3)$ & $2.0(0.5$ to 7.6$)$ & NS \\
\hline Diabetes & $7(6)$ & $5(4)$ & 1.5 (0.5 to 5.1$)$ & NS \\
\hline Hypothyroidism & $4(4)$ & $0(0)$ & Not estimable & $<0.02$ \\
\hline Immunosuppressive & $8(7)$ & $1(1)$ & 9.3 (1.2 to 73.4$)$ & $<0.004$ \\
\hline
\end{tabular}

therapy ${ }^{\ddagger}$

*Pulmonary disease includes bronchitis, emphysema, tuberculosis, and asthma; ${ }^{\dagger}$ The odds ratio for collagen vascular disease controlling for immunosuppression was statistically significant (OR 4.2; 95\% Cl 1.3 to 13.9; $P=0.02$ ). The odds ratio for immunosuppression, calculated while controlling for collagen vascular disease, was statistically significant (OR 9.6, 95\% Cl 1.1 to 82.0;

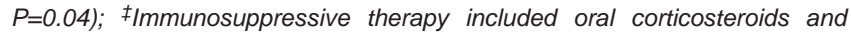
methotrexate. None of the blastomycosis patients or control subjects had human immunodeficiency virus (HIV) infection or organ transplantation. NS Not significant

TABLE 4

Social history and habits in 109 patients with blastomycosis and 116 control subjects*

\begin{tabular}{|c|c|c|c|c|}
\hline Variable & $\begin{array}{c}\text { Patients, } \\
\text { n (\%) }\end{array}$ & $\begin{array}{c}\text { Controls, } \\
\text { n (\%) }\end{array}$ & $\begin{array}{c}\text { Odds ratio } \\
(95 \% \mathrm{Cl})\end{array}$ & $\mathbf{P}$ \\
\hline Consume alcohol $^{\dagger}$ & 90 (83) & $94(81)$ & 1.2 (0.5 to 2.8$)$ & NS \\
\hline \multicolumn{5}{|l|}{ Smoking history ${ }^{\ddagger}$} \\
\hline Present or past & $51(47)$ & $49(42)$ & $1.2(0.7$ to 2.2$)$ & NS \\
\hline Present only & $12(11)$ & $16(14)$ & 0.5 (0.1 to 1.5$)$ & NS \\
\hline Drug abuse $e^{\S}$ & $12(11)$ & $4(3)$ & 8.5 (1.6 to 45$)$ & $<0.005$ \\
\hline \multicolumn{5}{|l|}{ Family social history } \\
\hline Married & $83(76)$ & $101(87)$ & $1.1(0.4$ to 3.1$)$ & NS \\
\hline Children & $84(77)$ & $101(87)$ & 0.8 (0.3 to 2.6$)$ & NS \\
\hline
\end{tabular}

${ }^{*}$ Data not available in 3 of the 112 patients with blastomycosis and in 2 of the 118 control subjects; 'Includes daily, weekly and occasional consumption; ${ }^{\ddagger}$ Number of pack-years in the upper 25th percentile: patients with blastomycosis, 15 pack-years; control subjects, 5 pack-years; $P=0.054$; ${ }^{\S}$ Drug abuse includes marijuana. NS Not significant

such as farming or digging, or pet dogs (Table 5). Furthermore, place of residence and travel history were similar in patients with blastomycosis and control subjects (Table 5).

After excluding the nonsignificant predictors in a series of backward stepwise modelling, four factors were determined to be independent predictors of developing blastomycosis: immunosuppression for any reason, including drugs or disease (adjusted OR 9.7; 95\% CI 1.1 to 84.2; $\mathrm{P}=0.04$ ), collagen vascular disease (adjusted OR, 4.7; 95\% CI 1.3 to $16.4 ; \mathrm{P}=0.016$ ), being an outdoor worker (adjusted OR 3.2; 95\% CI 1.2 to 8.4; $\mathrm{P}=0.015$ ) and having a coworker with blastomycosis (adjusted OR $5.9 ; 95 \%$ CI 1.1 to $32.5 ; \mathrm{P}=0.042$ ).

\section{DISCUSSION}

The present study confirms that there are identifiable risk factors for increased susceptibility to blastomycosis that may facilitate early diagnosis of this condition in endemic areas. 


\begin{tabular}{|c|c|c|c|}
\hline $\begin{array}{l}\text { Residential, travel, and } \\
\text { social contact factor }\end{array}$ & $\begin{array}{l}\text { Patients, } \\
\text { n (\%) }\end{array}$ & $\begin{array}{l}\text { Controls, } \\
\text { n (\%) }\end{array}$ & $\mathbf{P}$ \\
\hline \multicolumn{4}{|l|}{ Place of residence } \\
\hline Endemic area* & $68(61)$ & $67(57)$ & NS \\
\hline City of Kenora & $49(44)$ & $50(42)$ & NS \\
\hline City (other than Kenora) & $8(7)$ & $13(11)$ & NS \\
\hline Farm (within 1 year before diagnosis) & $3(3)$ & $5(4)$ & NS \\
\hline $\begin{array}{l}\text { Travel (vacation) to endemic area in } \\
\text { summer }\end{array}$ & $24(21)$ & $31(26)$ & NS \\
\hline \multicolumn{4}{|c|}{ Contact with humans or animals that had ever had blastomycosis } \\
\hline Pet $\operatorname{dog}^{\dagger}$ & $14(13)$ & $21(18)$ & NS \\
\hline Neighbor ${ }^{\ddagger}$ & $10(9)$ & $18(15)$ & NS \\
\hline Coworker ${ }^{\S}$ & $9(8)$ & $3(3)$ & NS \\
\hline \multicolumn{4}{|c|}{ Others who acquired blastomycosis at the same time } \\
\hline Coworker ${ }^{\S}$ & $8(7)$ & $2(2)$ & NS \\
\hline Neighbor ${ }^{\ddagger}$ & $8(7)$ & $10(8)$ & NS \\
\hline Friend & $9(8)$ & $11(9)$ & NS \\
\hline
\end{tabular}

*Residence in all of the areas of increased endemic occurrence of blastomycosis in Ontario including Keewatin, Sioux Narrows, Kenora; ${ }^{+}$Living with pets diagnosed with blastomycosis 12 months before or after patient diagnosis; ${ }^{\ddagger}$ Neighbor (other than study patients with blastomycosis) with diagnosis of blastomycosis; ${ }^{\S}$ Although not reflected in comparisons using $\chi^{2}$ tests, backward stepwise modelling showed that having a coworker with blastomycosis was a significant independent predictor for developing blastomycosis (adjusted OR 5.9; $95 \% \mathrm{Cl} 1.1$ to $32.5 ; P=0.042)$. NS Not significant

Independent risk factors for the development of blastomycosis included immunosuppression for any reason (including drugs or disease), collagen vascular disease, being an outdoor worker and having a coworker with blastomycosis.

Control subjects were not selected from the general population but rather from neighbours of the patients, potentially introducing selection bias. However, by controlling for residential environment in this manner, the significant differences observed between patients and control subjects may be attributed to the independent risk factors that were identified, without the potential for confounding the results with residential differences between patients and control subjects.

Cellular immunity is fundamental to host defence against $B$ dermatitidis and other fungi $(19-21,29,30)$. Thus, loss or compromise of immune defense leads to increased susceptibility and perhaps even facilitates growth of $B$ dermatitidis $(30,31)$. The present finding is in keeping with previous reports of blastomycosis in other patients immunocompromised from organ transplantation, glucocorticosteroid therapy, pregnancy, cytotoxic chemotherapy for hematological malignancies or solid tumours, or HIV infection $(19,20)$. The effect of HIV infection and organ transplantation on susceptibility to blastomycosis could not be confirmed in the present study because none of the patients or control subjects had HIV infection or organ transplantation. The present results also suggest an increased risk for individuals with hypothyroidism, but this finding requires further study because of the small number of blastomycosis patients with hypothyridism and lack of control subjects with thyroid disorders.

The patients and control subjects who participated in this study had lived in or visited either southeastern Manitoba or northwestern Ontario, areas known as endemic for
$\mathrm{B}$ dermatitidis. The area has been classified as a forest climate zone receiving an average annual precipitation from $50 \mathrm{~cm}$ to $81 \mathrm{~cm}$ (annual average, 140 days of precipitation) (32). Vegetation varies from wet, poorly drained areas (feather moss) to a discontinuous organic mat on bedrock (33). The forest floor is mainly covered in broadleaf litter in clayey soils, whereas sandy or coarse loamy soils are associated with a broad range of vegetation. Coniferous trees, including jack, red and white pine, and black spruce, contribute to the slightly acidic $\mathrm{pH}$. These climatic conditions are similar those described by other authors as providing a suitable growth environment for $B$ dermatitidis $(1,3)$.

Previous research that had suggested an association between canine and human blastomycosis infection (10,24-27), including early detection of human blastomycosis in dog owners (24) and simultaneous infection of dogs and humans who had been in contact with those dogs $(24,26,27)$; however, the present results showed no significant association between human and canine blastomycosis. Although other authors have suggested that blastomycosis is acquired close to the patient's domicile, it is impossible to control and predict where dogs will go when free to roam (34).

Occupational exposure from both outdoor activities and exposure to infected coworkers were significant independent risk factors for blastomycosis in the present study. Previous studies have identified soil and organic debris near waterways as the most significant environment for the transmission of $B$ dermatitidis due to the optimal growing conditions for $B$ dermatitidis, including moist soil, high humidity, decaying organic debris, animal excrement, mechanical disruption of the soil, and air currents that carry the aerosolized conidia $(1,17)$. These conditions exist elsewhere including inside the attics and basements of some domiciles (34), but a greater likelihood of exposure to the fungus may occur near waterways during recreational activities (17). The observation of increased risk in coworkers who had blastomycosis is compatible with the reports of others, because it likely represents a point source exposure $(8,14,17,18,26,34-36)$.

The present study confirmed male sex (Table 2) as a risk factor associated with, albeit not an independent risk factor for, increased susceptibility for blastomycosis infection. Previous studies have suggested that male sex is associated with increased risk of blastomycosis (14), but other studies have not shown an increased risk for blastomycosis with age, sex, race, occupation or seasonal predilection $(8,10,37)$. Others have suggested that increased environmental exposure is a significant risk factor for the development of blastomycosis $(17,18,26,38,39)$.

Limitations of the study are similar to those inherent with a cross sectional, retrospective case control survey. Selection bias towards milder cases may have resulted because patients who had died were not included, potentially precluding the identification of risk factors for more severe cases. Limited statistical power because of the sample size may have resulted in limited identification of some risk factors, but it was not feasible to perform a power analysis because the study was done from a convenience sample of those who replied to a request to participate; this was unavoidable because of local confidentiality legislation. Recall bias may have occurred because patients had been asked to recall details of the illness, in some cases from up to 251 months prior. The number of cases, particularly in 
Aboriginal people, may have been underestimated due to recruitment strategy, but this was unavoidable because of confidentiality legislation. Another potential limitation was that the controls were identified by the blastomycosis patients and, by definition, were people who had not had clinical disease compatible with blastomycosis; it is possible that some of the control subjects may have had subclinical blastomycosis because less than one-half of those infected may develop clinical infection $(17,40)$.

\section{REFERENCES}

1. Denton JF, McDonough ES, Ajello L, et al. Isolation of Blastomyces dermatitidis from soil. Science 1961;133:1126-7.

2. Dixon OM, Shadomy H. In vitro growth and sporulation of Blastomyces dermatitidis on woody plant material. Mycologia 1977;69:1193-4.

3. Bakerspigel A, Kane J, Schaus D. Isolation of Blastomyces dermatitidis from an earthen floor in southwestern Ontario, Canada. J Clin Microbiol 1986;24:890-1.

4. Sarosi GA, Serstock DS. Isolation of Blastomyces dermatitidis from pigeon manure. Am Rev Resp Dis 1976;114:1179-83.

5. Schwarz J, Baum GL. Blastomycosis. Am J Clin Pathol 1951;21:999-1029.

6. Chapman SW. Blastomyces dermatitidis. In: Mandell GL, Bennett JE, Dolin R, eds. Mandell, Douglas, Bennett's Principles and Practice of Infectious Diseases, 6th edn. Philadelphia: Elsevier; 2005:3026-40.

7. Crampton TL, Light RB, Berg GM, et al. Epidemiology and clinical spectrum of blastomycosis diagnosed at Manitoba hospitals. Clin Infect Dis 2002;34:1310-6.

8. Baumgardner DJ, Steber D, Glazier R, et al. Geographic information system analysis of blastomycosis in northern Wisconsin, USA: Waterways and soil. Med Mycol 2005;43:117-25.

9. Dwight PJ, Naus M, Sarsfield P, et al. An outbreak of human blastomycosis: The epidemiology of blastomycosis in the Kenora catchment region of Ontario, Canada. Can Commun Dis Rep 2000;26:82-91.

10. Baumgardner DJ, Buggy BP, Mattson BJ, et al. Epidemiology of blastomycosis in a region of high endemicity in north central Wisconsin. Clin Infect Dis 1992;15:629-35.

11. Chapman SW, Lin AC, Hendricks KA, et al. Endemic blastomycosis in Mississippi: Epidemiological and clinical studies. Semin Respir Infect 1997;12:219-28.

12. Centers for Disease Control and Prevention (CDC). Blastomycosis - Wisconsin, 1986-1995. MMWR Morb Mortal Wkly Rep 1996;45:601-3.

13. Cano MV, Ponce-De-Leon GF, Tippen S, et al. Blastomycosis in Missouri: Epidemiology and risk factors for endemic disease. Epidemiol Infect 2003;131:907-14.

14. Furcolow ML, Busey JF, Menges RW, et al. Prevalence and incidence studies of human and canine blastomycosis II: Yearly incidence studies in three selected states, 1960-1967. Am J Epidemiol 1970;92:121-31.

15. Baumgardner DJ, Halsmer SE, Egan G. Symptoms of pulmonary blastomycosis: northern Wisconsin, United States. Wilderness Environ Med 2004;15:250-6.

16. Davies SF, Sarosi GA. Epidemiological and clinical features of pulmonary blastomycosis. Semin Respir Infect 1997;12:206-18.

17. Klein BS, Vergeront JM, DiSalvo AF, et al. Two outbreaks of blastomycosis along rivers in Wisconsin: Isolation of Blastomyces dermatitidis from riverbank soil and evidence of its transmission along waterways. Am Rev Respir Dis 1987;136:1333-8.

18. Cockerill FR, Roberts GD, Rosenblatt JE, et al. Epidemic of pulmonary blastomycosis (Nanekagan fever) in Wisconsin canoeists. Chest 1984;86:688-92.

19. Pappas PG, Threlkeld MG, Bedsole GD, et al. Blastomycosis in immunocompromised patients. Medicine 1993;72:311-25.
ACKNOWLEDGEMENTS: The authors thank the following for invaluable assistance: the medical records departments at the Lake of the Woods District Hospital, Health Sciences Centre, and Brandon, Concordia, Grace, St Boniface, Seven Oaks, and Victoria General Hospitals; Carolyn Garlinski and Debbie Ormiston (Infection Prevention and Control Unit, Health Sciences Centre); and Maryanne Kennedy, Lorraine Kuzyk and Pam Schille (Infectious Diseases Research Unit, Health Sciences Centre).

20. Serody JS, Mill MR, Detterbeck FC, et al. Blastomycosis in transplant recipients: Report of a case and review. Clin Infect Dis 1993;16:54-8.

21. Lemos LB, Baliga M, Guo M. Blastomycosis: The great pretender can also be an opportunist. Initial clinical diagnosis and underlying disease in 23 patients. Ann Diagn Pathol 2002;6:194-203.

22. Gauthier GM, Safdar N, Klein BS, et al. Blastomycosis in solid organ transplant recipients. Transpl Infect Dis 2007;9:310-7.

23. Ismail MA, Lerner SA. Disseminated blastomycosis in a pregnant woman: Review of amphotericin B usage during pregnancy. Am Rev Respir Dis 1982;126:350-3.

24. Sarosi GA, Eckman MR, Davies SF, et al. Canine blastomycosis as a harbinger of human disease. Ann Intern Med 1979;91:733-5.

25. Cote E, Barr SC, Allen C, et al. Blastomycosis in six dogs in New York state. J Am Vet Med Assoc 1997;210:502-4.

26. Armstrong CW, Jenkins SR, Kaufman L, et al. Common-source outbreak of blastomycosis in hunters and their dogs. J Infect Dis 1987;155:568-70.

27. Schwarz J. Epidemiology and epidemics of blastomycosis. Mykosen 1983;26:7-14.

28. International Classification of Diseases. International Classification of Diseases. 9th Revision. Clinical Modification. 4th edition. Los Angeles: Practice Management Information Corporation (PMIC), 1994.

29. Bradsher RW, Chapman SW, Pappas PG. Blastomycosis. Infect Dis Clin North Am 2003;17:21-40.

30. Pappas PG. Blastomycosis in the immunocompromised patient. Semin Respir Infect 1997;12:243-51.

31. Conces DJ. Endemic fungal pneumonia in immunocompromised patients. J Thorac Imaging 1999;14:1-8.

32. Natural Resources Canada. The Atlas of Canada. <http://atlas. nrcan.gc.ca/site/english/maps/archives/4thedition/environment/ climate/047_48> (Version current June 28, 2007).

33. Sims RA, Towill WD, Baldwin KA, et al. Field guide to the forested ecosystem classification for northwestern Ontario. Thunder Bay, Ontario: Ministry of Natural Resources, Northwest Science and Technology, 1997.

34. Baumgardner DJ, Paretsky DP. Blastomycosis: More evidence for exposure near one's domicile. WMJ 2001;100:43-5.

35. Baumgardner DJ, Paretsky DP, Yopp AC. The epidemiology of blastomycosis in dogs: North central Wisconsin, USA. J Med Vet Mycol 1995;33:171-6.

36. Sarosi GA, Davies SF. Blastomycosis. Am Rev Respir Dis 1979;120:911-38.

37. Lowry PW, Kelso KY, McFarland LM. Blastomycosis in Washington Parish, Louisiana, 1976-1985. Am J Epidemiol 1989;130:151-9.

38. Baumgardner DJ, Paretsky DP. The in vitro isolation of Blastomyces dermatitidis from a woodpile in north central Wisconsin, USA. Med Mycol 1999;37:163-8.

39. Kaplan W, Clifford MK. Blastomycosis. I. A review of 198 collected cases in Veterans Administration Hospitals. Blastomycosis Cooperative Study of the Veterans Administration. Am Rev Respir Dis 1964;89:659-72.

40. Vaaler AK, Bradsher RW, Davies SF. Evidence of subclinical blastomycosis in forestry workers in northern Minnesota and northern Wisconsin. Am J Med 1990;89:470-6. 


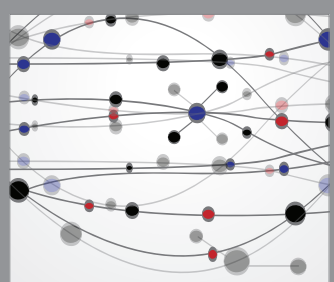

The Scientific World Journal
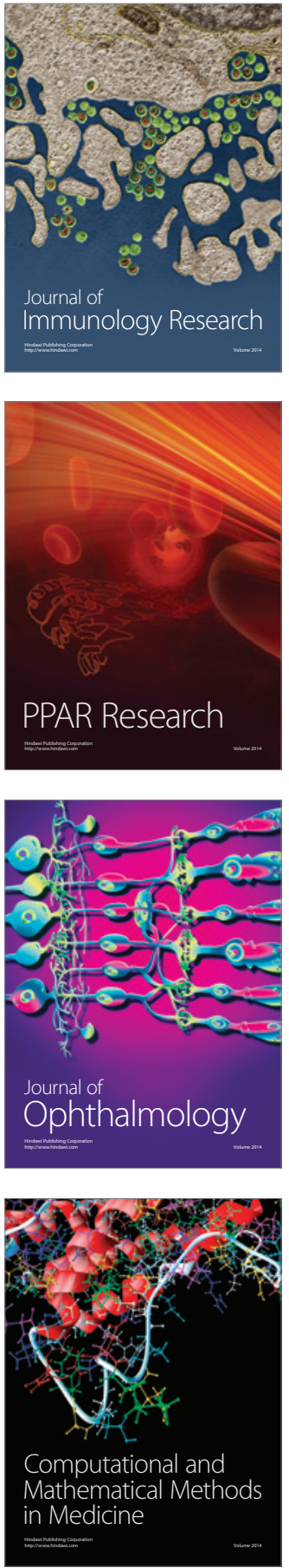

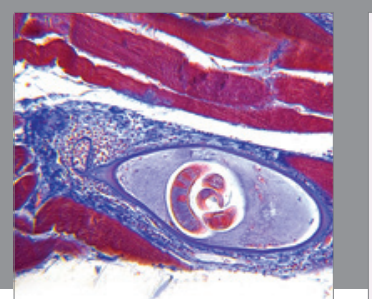

Gastroenterology Research and Practice

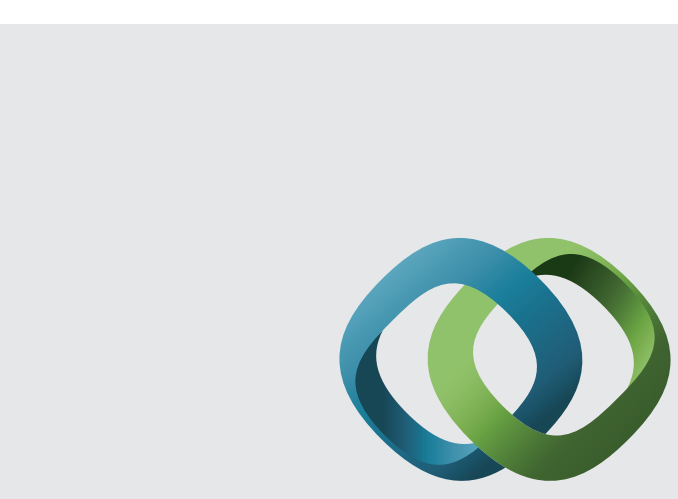

\section{Hindawi}

Submit your manuscripts at

http://www.hindawi.com
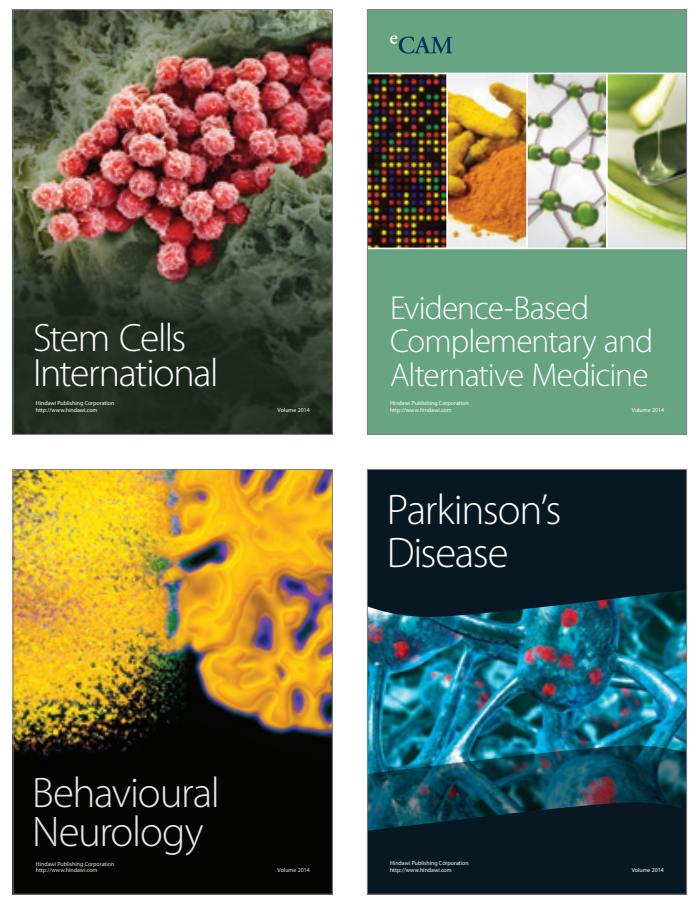
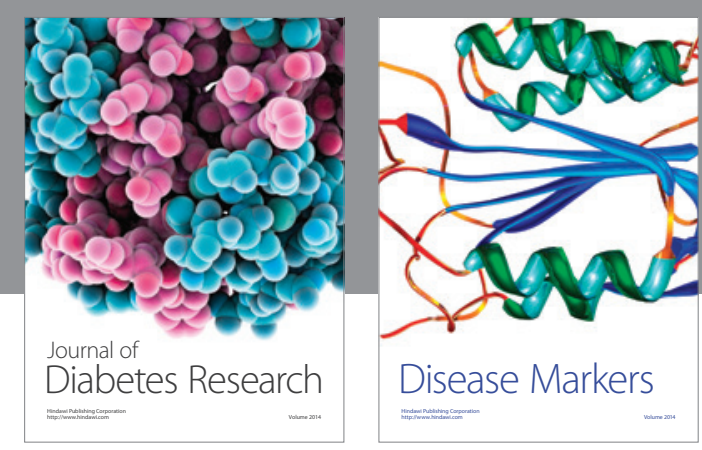

Disease Markers
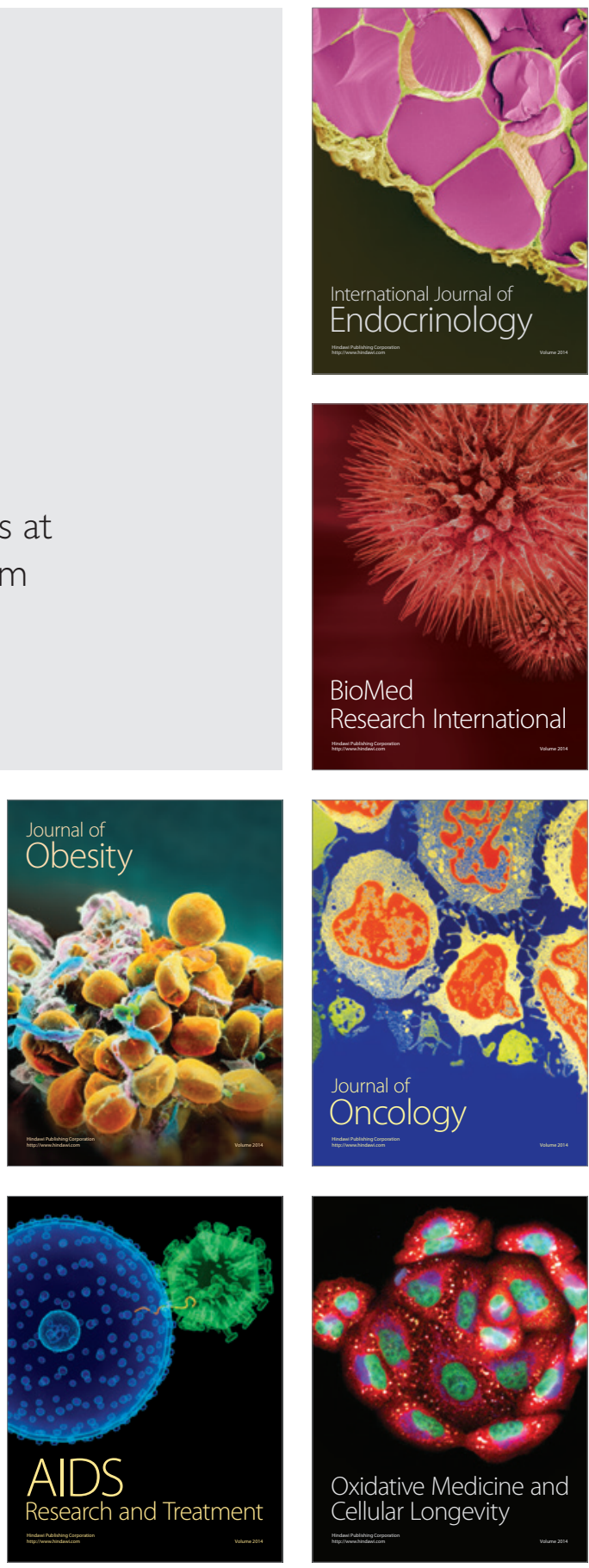